\title{
CARNIVOROUS WALRUS AND SOME ARCTIC ZOONOSES*
}

\author{
Francis H. Fay†
}

\section{Introduction}

$\mathbf{T}$ HAT walrus (Odobenus rosmarus) sometimes develop a habit of eating seals is generally recognized by arctic maritime Eskimos and has been mentioned frequently in scientific and popular literature. The role of walrus as hosts of Trichinella spiralis seems obviously related to this unusual carnivorous habit (the term "carnivorous" is used in this paper in the restricted sense of "eating warm-blooded animals"). The Eskimos are further aware of a pathologic condition in man that has been associated with consumption of liver from such flesh-eating animals. Little is known of the ecology of carnivorous walrus, largely because of their scarcity and the remoteness of their habitat. There is however a considerable volume of fragmentary information on this subject in various biological reports and in Eskimo lore. The purpose of this paper is to review the available information and to discuss the potential importance of these animals as a source of diseases transmissible to man. A brief discussion of the arctic marine trichinosis cycle is also included, with emphasis on host ecology and parasite transmission.

I am indebted to Dr. Robert Rausch and Dr. Christine Heller, Arctic Health Research Center, Anchorage, Alaska, and Dr. Arthur Mansfield, Fisheries Research Board of Canada, Montreal, Quebec, for supplying some unpublished data used in this review. Dr. Rausch and Mr. Francis S. L. Williamson, also of the Arctic Health Research Center, have given valuable assistance by critical reviews of the manuscript.

\section{Carnivorous walrus}

The most remarkable morphological character of walrus is their greatly enlarged canine teeth that are possessed by both sexes. It has generally been presumed that these tusks are an adaptation for digging molluscs, since walrus are bottom feeders in the shallow waters of the continental shelves. Occasionally, some individuals deviate from their usual diet to feed on mammals, and the aggressiveness and predatory tendencies of these carnivorous individuals evidently have been known to aborigines in Greenland,

*Zoonoses are diseases of animals that can be transmitted to man.

$\dagger$ Arctic Health Research Center, Public Health Service, U.S. Department of Health, Education, and Welfare, Anchorage, Alaska. 
arctic America, and northeastern Siberia for many years. Strips or chunks of skin and blubber from ringed seals (Pusa hispida) and bearded seals (Erignathus barbatus) have been found in the stomachs of walrus killed in northern Canada (Freuchen 1935, Collins 1956, Mansfield 1958), Greenland (Johansen 1912, Pedersen 1930, Vibe 1950), Franz Josef Land (Tsalkin 1937), Novaya Zemlya (Chapskii 1936), and Alaska (Brooks 1954), and in northeastern Siberia seal remains were found in walrus faeces by Nikulin (1941). The Eskimos believe, and most published records show, that the carnivores are all males. Apparently the only known carnivorous female was one taken in East Greenland and reported by Pedersen (1930).

From details in the papers cited and from personal interviews with Eskimos in the Bering Strait region, I conclude that flesh-eating walrus are largely divisible into facultative and obligate types, with some intergradation. The facultative type, which eats mammals only when invertebrates are absent or inaccessible (Chapskii 1936, Vibe 1950), seems to be the more common of the two, especially in the Eastern Canadian Arctic, Greenland, and Svalbard. In these regions, walrus frequently occupy waters too deep for benthic feeding or areas in which food is scarce. As an example, Vibe reported that walrus migrating across the north side of Melville Sound in spring almost always have empty stomachs due to inaccessibility of food in the deep water. He found remains of ringed seal in the stomachs of two among about one hundred of these migrants taken at Neqe in 1939-41.

The obligate carnivore has never to my knowledge been observed by a biologist; the description of this type is based entirely on verbal reports from Eskimos. The obligate carnivores or "rogues" are said to be solitary bulls that feed principally or exclusively on vertebrates. In contrast to the facultative type, which is distinguishable from non-carnivores only by the stomach contents, the obligate carnivore has often a characteristic external appearance. It is relatively lean and slender, with shoulders and forelimbs appearing unusually large and powerfully developed; the chin, neck, and breast are impregnated with oil from frequent contact with seal blubber, and the oxidized oil imparts an amber colour to these regions and to the tusks (cf. Brooks 1954, p. 57). The tusks are exceptionally long, slender, and sharppointed, and their labial surfaces are covered with scratches. The exceptional length of the tusks might be due to a lack of the attrition which normally shortens the tusks of benthic feeders (Fay 1955, Mansfield 1958).

Obligate carnivores evidently constitute less than 0.1 per cent of the walrus population in the Bering and Chukchi seas, for out of more than 3000 walrus taken from 1952 to 1959 by the Eskimos of St. Lawrence Island, Alaska only three were of this type. The proportion of facultative carnivores is unknown but is believed to exceed 1.0 per cent.

There is as yet no objectively gathered information regarding the conditions that induce the drastic, total modification of diet from molluscs to mammals, thereby creating an obligate carnivore. A traditional explanation is part of the folklore of Alaskan Eskimos (Fay 1955) and of walrus hunters in the Soviet Far East (Kleinenberg 1957). It is said by these people that 
calves whose mothers are separated from them in the first year or two of life are not sufficiently familiar with bottom feeding techniques to sustain themselves. Lacking parental assistance, some are able to survive only by scavenging and preying on whatever organisms they can capture. These rare survivors simply continue to scavenge and prey for the rest of their lives.

Conclusive evidence of predation by walrus has never been reported in the literature. Freuchen (1935) indicated that some adult walrus will eat carrion, and Mansfield (1958) also thought the seal remains found in a stomach to be carrion. Predation was indicated by Hantzsch's (1913, p. 155) remark that the Eskimos of eastern Baffinland had repeatedly seen walrus catch seals with their foreflippers, but only Pedersen (1930) has obtained specific information suggesting predation. In East Greenland, Pedersen examined a seal that had been mauled by a walrus and concluded that the seal died as a result of having been crushed by the forelimbs of the walrus. Although this seems credible, some doubt exists about the interpretation, for Pedersen did not actually observe the chase and kill, and the seal could have been dead before it was taken by the walrus. An incident at Barrow, Alaska, in which a walrus carried away a dead seal, was reported by Okak (1956), and there are many other non-documented accounts of this type in Alaskan Eskimo lore. Freuchen (1935) noted that the Cape York Eskimos have been known to "fish" for walrus, using dead seals as bait.

In the behavioural responses of seals to walrus there is yet another indication of interspecific aggression, though not necessarily of predator-prey relationship. Walrus are at the top of the interspecific social hierarchy among northern pinnipeds (Hediger 1955), and their dominance over phocid seals of some genera is particularly strong, even in captivity. Ringed seals especially tend to desert or avoid areas occupied by walrus, and the Eskimos state that the presence of an obligate carnivore magnifies this reaction enormously. Some groups of coastal Eskimos who depend upon a supply of seals for food and clothing endeavor to kill such invading carnivores immediately, in order to allow the seals to return to the hunting grounds (Bailey and Hendee 1926, Nikulin 1941).

Carnivorous walrus are also known to feed on whales, but again there is no conclusive evidence of predation. Both Brown (1868) and Freuchen (1935) have reported that dead whales are eaten when benthos is not available, and fights between walrus and whales, which may rarely lead to the death of the latter, have been described. A battle between two walrus and a beluga (Delphinapterus leucas) was observed by Tulin (Chapskii 1936) in the Kara Sea, but Chapskii considered this incident atypical since he had seen walrus and belugas side by side with no indication of hostility. The action observed by Tulin, however, has been repeated in captivity by a young bull walrus that attacked a beluga in the aquarium of the New York Zoological Society (Schumach 1958). Further plausible evidence of such aggressive behaviour on the part of walrus was discovered on St. Lawrence Island, Alaska in the fall of 1956. A dead gray whale (Eschrichtius glaucus) that stranded near the village of Savoonga was found to have a broken walrus tusk in its 
head. According to the Eskimos the slender tusk, evidently from a juvenile animal, was yellow-brown in colour, indicating that it had been embedded for a long time and had not been the cause of death.

Thus it is clear that some walrus eat other marine mammals habitually or under stress of starvation, and it appears possible that some walrus actively pursue and kill seals for food. It seems impossible to determine the number of seals eaten by an individual carnivore, but during the relatively long life span of walrus (up to 20-30 years: Fay 1955, Mansfield 1958), an habitual or obligate carnivore could conceivably eat parts of hundreds of the smaller species (e.g., Pusa hispida). In doing so, the obligate carnivore must become exposed to the same nutritional and parasitological conditions as the polar bear (Thalarctos maritimus), for the bear feeds principally on ringed and bearded seals (Pedersen 1945). From the seals the polar bear evidently acquires a hyperconcentration of vitamin A (Rodahl 1949) and frequently an infection of Trichinella spiralis (cf. Rausch et al. 1956). Indeed, there are some indications that carnivorous walrus do acquire a high concentration of vitamin A equivalent to that of bears and the presence of Trichinella in walrus flesh has been reported several times.

\section{Carnivorous walrus and hypervitaminosis-A}

Walrus are much hunted and widely used as food by coastal Eskimos and some other northern aborigines, but all these people are reluctant to eat the flesh and especially the viscera of carnivorous walrus. The meat of the carnivores is "rank and bitter" (Freuchen 1935, p. 250), and the liver is customarily discarded because of its alleged toxic quality (Klutschak 1881, Collins 1956). According to the Eskimos of St. Lawrence and Little Diomede islands, Alaska the sickness produced by eating the liver is the same as that produced by eating polar bear liver. The Eskimos describe this as headache, nausea, and debility, followed or accompanied by peeling of the skin (especially about the face and forelimbs) and loss of hair. Høygaard (1937) and others (see Nieman and Obbink 1954) have described similar general signs following ingestion of polar bear liver, and Rodahl $(1949,1950)$ produced these signs experimentally in laboratory animals. Rodahl concluded from his experiments that the toxic effect of livers from polar bears and some other arctic mammals is due principally to a hyperconcentration of vitamin $A$.

In walrus feeding on benthos the vitamin A content of the liver is probably quite low. Rodahl $(1949$, p. 71$)$ found only "traces" in the one specimen that he examined, and one other, processed by the Biochemistry and Nutrition Section, Arctic Health Research Center (C. Heller, personal communication), contained about 500 International Units per gram - a moderate content. Unfortunately, there have been no biochemical assays of livers from carnivorous walrus for comparison. The similarity between the diets of obligate carnivores and polar bears suggests similar hepatic concentrations of vitamin A. In the bears this may amount to a content of 13,000 to 18,000 I. U. per gram (Rodahl 1949), a concentration that is toxic to man. 
Both the carnivorous walrus and the polar bear feed extensively on the skin and blubber of ringed and bearded seals, and it is quite certain that most of the vitamin $\mathrm{A}$ is acquired from the blubber. Fresh blubber from ringed and bearded seals taken in the Bering and Chukchi Seas contains 40-50 I. U. of vitamin A per gram (C. Heller, personal communication) and as much as a million I. U. could be present in the blubber of one seal.

The chances of vitamin A-charged walrus liver being eaten by man seem negligible, for not only are the obligate carnivores rare, they evidently are easily recognized and can be avoided. The Eskimos routinely dispose of such livers and only occasionally save some flesh and blubber for dogfood. Since Caucasians are generally reluctant to eat any part of such "unusual" mammals as walrus, they are practically free from this potential health hazard.

\section{Carnivorous walrus and trichinosis}

Although Trichinella spiralis has been known as a parasite of man and other mammals for more than a century, its presence in the arctic fauna was not recognized until 1934, when Parnell (1934) found larvae encysted in the muscles of polar bear and arctic fox (Alopex lagopus). Some years after this important discovery, and following an epidemic of trichinosis in the Eskimos of West Greenland (Thorborg et al. 1948), scientific interest in arctic trichinosis was aroused. Extensive surveys of the boreal fauna for evidence of Trichinella infection were begun, with special attention given to those species of mammals that are staple foods of northern aborigines and explorers. The results of these investigations demonstrated the prevalence of the parasite in a wide variety of hosts (e.g., Rausch et al. 1956), and among the more interesting discoveries was the fact that such mammals as ringed seals, bearded seals, and walrus are occasionally infected (Roth and Madsen 1953).

Trichinella is primarily a parasite of carnivores, and its transmission is mainly accomplished by one mammal eating the infected flesh of another. Of all wild arctic mammals examined, polar bears were found to be the most frequently infected. As noted above, the bears feed almost exclusively on ringed and bearded seals, and it is probable that infective larvae are acquired from this source. From where the seals contract their infections and the method of larval transmission are unknown, since neither Erignathus nor $P u s a$ is known to be carnivorous.

Regarding walrus, it would be expected that the carnivorous individuals are the ones that become infected, and this view seems to be supported by a comparison of the trichinosis survey data with material from other sources (Table 1). The data show a positive correlation between the percentage of carnivorous walrus and the percentage of walrus infected with $T$. spiralis. Unfortunately, this situation is rather more complicated than the data in Table 1 imply. It is unlikely, for example, that the sex and age compositions of the samples are uniform and representative of the populations from which they were drawn; therefore the comparison may not be valid. Since nearly 
all carnivorous walrus are males, most of the infected animals should also be males, and the incidence of infection should increase with the amount of flesh eaten (viz., with increasing age and propensity for a flesh diet). Thus, in order to determine satisfactorily the role of carnivorous walrus as carriers of trichinosis, it would be necessary to classify each walrus examined as to sex, age, diet, and the presence or absence of Trichinella. In the data available to me, this can be done with only ten animals (Table 2), an insignificantly small sample. This sample could be interpreted as indicating no relationship between diet and trichinosis, or, conversely, the infected animals could have been facultative carnivores that were not recognized as such. The data at

Table 1. Comparative frequency of occurrence of carnivores and Trichinella infections in some walrus populations.

\begin{tabular}{lcccc}
\hline \multicolumn{1}{c}{ Region } & $\begin{array}{c}\text { Walrus stomachs } \\
\text { examined } \\
\text { Per cent } \\
\text { with seal } \\
\text { remains }\end{array}$ & $\begin{array}{c}\text { Number } \\
\text { with food }\end{array}$ & $\begin{array}{c}\text { Wumber } \\
\text { foramined }\end{array}$ & $\begin{array}{c}\text { Per cent } \\
\text { infected }\end{array}$ \\
\hline Canadian Eastern Arctic & 35 & 3 & 401 & 4 \\
Greenland (mostly West) & 100 & 2 & 481 & 1 \\
Kara Sea to Denmark Strait & 36 & 11 & 74 & 10 \\
Alaska & 30 & 0 & 104 & 1 \\
\hline
\end{tabular}

* Data from Mansfield 1958 (Canada), Vibe 1950 (Greenland), Chapskii 1936 (Kara Sea), Tsalkin 1937 (Franz Josef Land), Brooks 1954, and Fay MS. (Alaska).

** Data from Brown et al. 1949a and Kuitunen 1954 (Canada), Roth and Madsen 1953 (Greenland), Thorshaug and Rosted 1956 (Barents Sea, Franz Josef Land and Svalbard waters, Greenland Sea, and Denmark Strait), Rausch et al. 1956 and Fay unpublished (Alaska).

Table 2. Age, sex, and diet of walrus examined for trichinosis.*

\begin{tabular}{ccccc}
\hline Location & Sex & $\begin{array}{c}\text { Estimated } \\
\text { age }(\text { yrs. }\end{array}$ & Carnivorousness** & $\begin{array}{c}\text { Trichinella } \\
\text { (larvae/gm.) }\end{array}$ \\
\hline Canada & M & 9 & no & 1 \\
Canada & M & 16 & no & 1 \\
Canada & M & 12 & no & 2 \\
Canada & M & 11 & yes & 540 \\
Alaska & M & 13 & no & 0 \\
Alaska & M & 12 & no*** & 0 \\
Alaska & F & 19 & no & 0 \\
Alaska & F & 20 & no & 0 \\
Alaska & F & 13 & no & 0 \\
\hline
\end{tabular}

* Canadian data from A. W. Mansfield (in litt.).

** Based on stomach contents: no = invertebrate, yes = seal.

*** Identified by Eskimos as possible carnivore, scratches on labial surface of tusks. 
least demonstrate that identification of infected walrus can only be done by laboratory methods and that in practice any walrus should be considered as a potential source of Trichinella larvae.

Before the infection in the Alaskan specimen (Table 2) was diagnosed (at Gambell, St. Lawrence Island, in January 1957), some partially-cooked flesh had been eaten by several Eskimos and raw flesh had been fed to at least twenty sledge dogs. The people and older dogs apparently were unaffected by the parasite, but two dogs, approximately three months old, became lethargic on the 4th day and vomited large quantities of mucus. One of the dogs died on the 5th day and on autopsy a dense population of Trichinella adults and larvae was found in its intestine. A few larvae were found also in blood smears. The second dog continued to vomit on the 5th day and expelled mucus containing numerous adult and larval Trichinella. This dog was apparently in good health by the 11th day when observation was terminated.

It is easy to imagine how several people in an isolated community might contract trichinosis from eating the raw flesh of a single infected walrus, but the Eskimos' frequent practice of boiling pinniped meat seems to preclude the possibility of any widespread epidemic. The epidemic of 1947 in West Greenland that was believed to have resulted principally from eating infected walrus meat (Thorborg et al. 1948, Skeller 1948) is therefore difficult to understand. It seems incredible that some 300 people (about 6 per cent of the population) in twelve widely separated settlements could have become infected within a 5 -month period from the very population of walrus out of which a harvest was taken and eaten annually. It is also difficult to explain the lack of infections in settlements immediately north of the area of the epidemic where walrus, apparently from the same migrant population, were also harvested and eaten annually. Since the proportion of infected walrus in Greenland waters is only about 1 per cent (Roth and Madsen 1953), such a widespread, yet restricted epidemic could have occurred only if the bulk of the people in the twelve southern settlements had eaten raw walrus meat whereas the people in the north ate cooked meat. Furthermore, such extensive consumption of raw meat could have taken place only in 1947; otherwise, epidemics of this sort should occur annually in the same region.

In casting doubt on the original interpretation of this incident, I do not intend to belittle the thorough investigations of Thorborg, Tulinius, Roth, and Skeller, for they succeeded in obtaining an impressive volume of diagnostic information under adverse field conditions. Judging from the clinical evidence, the epidemic must have been trichinosis, but it is my opinion that the source of infected meat was incorrectly identified.

Thorborg and associates noted that the southern edge of the epidemic area conformed to the southern limit of the distribution of sledge dogs. It was also noted that the dogs (61 per cent infected: Roth and Madsen 1953) were considered a delicacy in the epidemic area but were not eaten to a great extent except in times of emergency. Finally, it was stated that the abnormally warm winter of 1946-7 resulted in poor hunting for some types 
of game (e.g., polar bears). These few points suggest to me the probability that dog flesh was the principal source from which the people contracted trichinosis. This was mentioned by Thorborg and his associates, but was considered no further because only 21 per cent of the patients queried admitted that they had eaten dog meat less than one month before the onset of illness. It seems likely, however, that the warm winter and consequent poor hunting in the southern settlements could have resulted in at least a moderate shortage of food and an ensuing increase in the amount of dog meat eaten. The fact that at least 21 per cent of the patients had eaten dog meat seems, in itself, to indicate that there was a state of "emergency." In the more northern settlements, outside the affected area, the warm winter should have had less effect on the hunting; more seals should have been available; and it was reported that in at least one locality reindeer were used.

It seems most reasonable to consider that the epidemic, an unusual situation, must have arisen as a result of unusual circumstances rather than from a routine annual occurrence such as consumption of walrus meat. I therefore suggest that the principal source of Trichinella causing the epidemic was infected dog meat and that walrus have been erroneously, or in too large a measure, implicated in this situation.

\section{The arctic marine trichinosis cycle}

In the foregoing, I have sought to emphasize that polar bears and carnivorous walrus contract trichinosis primarily by eating infected flesh of ringed and bearded seals. I have deduced this from the fact that polar bears eat parts of a great number of seals, and some seals are known to be infected. The frequency of infection in the bears (over 50 per cent in most of the Arctic) also suggests that the source of larvae is some common item in the diet. It is my impression that the seal-to-bear transmission has been underrated by some investigators, perhaps because of the great difference between the incidences of infection in the seals and in the bears (Table 3 ). It is apparent, however, that the intermediate and final hosts of endoparasites often show a great disparity in infection rates when a predatorprey relationship exists between these hosts. For example, Rausch (1952) found 25 per cent of snowy owls (Nyctea scandiaca) in northern Alaska infected with the cestode Paruterina candelabraria, but he found no larvae of this parasite in nearly two thousand microtine rodents (the intermediate hosts) from the same region. Another cestode, Taenia polyacantha, occurs in about 85 per cent of arctic foxes on St. Lawrence Island, but less than 0.5 per cent of the microtine rodents on the island are infected with the larvae (Fay and Williamson unpublished). Trichinella spiralis, of course, has no separate intermediate hosts, but for seals and bears the statistics of host-to-host transmission must be comparable. It seems significant, for example, that the frequency of infection in Alaskan polar bears is twice that of bears from Greenland (Table 3), where ringed seals are rarely infected. 
Table 3. Incidence of Trichinella spiralis in some arctic marine mammals.*

\begin{tabular}{|c|c|c|c|c|c|c|}
\hline \multirow[b]{2}{*}{ Region } & \multicolumn{2}{|c|}{ Polar bears } & \multicolumn{2}{|c|}{ Ringed seals } & \multicolumn{2}{|c|}{ Bearded seals } \\
\hline & $\begin{array}{l}\text { Number } \\
\text { examined }\end{array}$ & $\begin{array}{l}\text { Per cent } \\
\text { infected }\end{array}$ & $\begin{array}{l}\text { Number } \\
\text { examined }\end{array}$ & $\begin{array}{l}\text { Per cent } \\
\text { infected }\end{array}$ & $\begin{array}{l}\text { Number } \\
\text { examined }\end{array}$ & $\begin{array}{l}\text { Per cent } \\
\text { infected }\end{array}$ \\
\hline Canada & 3 & 67 & - & - & - & - \\
\hline Greenland & 247 & 23 & 1561 & 0.06 & 243 & 0.8 \\
\hline $\begin{array}{l}\text { Barents Sea to Denmark } \\
\text { Strait }\end{array}$ & 295 & 58 & 8 & 0.0 & 300 & 0.0 \\
\hline Alaska & 104 & 55 & 300 & 0.7 & 148 & 0.7 \\
\hline
\end{tabular}

*Data from Brown et al. 1949a (Canada), Roth and Madsen 1953 (Greenland), Thorshaug and Rosted 1956 and Aaser in Connell 1949, p. 103 (Barents Sea, Franz Josef Land and Svalbard waters, Greenland Sea, and Denmark Strait), Rausch et al. 1956 and Rausch unpublished (Alaska).

Possibly some polar bears could become infected by eating carrion, such as the carcasses of sledge dogs and other bears (Rausch et al. 1956), but the available information indicates that this occurs too infrequently to be the principal method of transmission. Also, a bear-walrus-bear-etc. cycle, as suggested by Cameron (1957), is altogether untenable, for the bears rarely eat walrus, and there is no evidence that walrus ever eat bears.

Pinnipeds other than ringed and bearded seals play an insignificant role as prey and as potential sources of infective larvae in the arctic marine trichinosis cycle. Neither polar bears nor carnivorous walrus are known to eat harp seals (Pagophilus groenlandicus), ribbon seals (Histriophoca fasciata), or hooded seals (Cystophora cristata) in appreciable numbers, and harbour seals (Phoca vitulina) generally occur too far south to enter into the arctic cycle. No Trichinella larvae were found in more than 2200 specimens of Pagophilus and Cystophora examined by Roth (1950) and Thorshaug and Rosted (1956).

The source from which ringed and bearded seals acquire T. spiralis larvae and the method of transmission are two problems remaining to be solved. Too little is known about the biology of these seals at present even to guess what the solutions may be. It has been shown that Erignathus feeds primarily on benthos, and Pusa feeds mostly on macroplankton (Pikharev 1941, Vibe 1950, McLaren 1958), and there is no evidence that mammalian flesh is ever eaten by either of them. McLaren found, however, that ringed seals feeding close to shore had such unusual items as leaves and feathers in their stomachs, and in Newfoundland Rosted (Thorshaug and Rosted 1956) observed seals ( $P$. vitulina?) eating meat scraps and foreflippers cut from young belugas.

An indirect or accidental method by which Trichinella larvae might be transmitted to seals has been suggested by Vibe (1950) and Roth and Madsen (1953). These investigators noted that amphipods, which rapidly congregate on and devour any vertebrate flesh that sinks to the bottom of northern seas, are eaten in large quantities by ringed seals and to some 
extent by bearded seals. In eating such swarms about infected carcasses of sledge dogs and polar bears, the seals might ingest some Trichinella larvae contained in the guts of the amphipods or in bits of meat inadvertently swallowed with them. A preliminary experiment to test this theory was undertaken on St. Lawrence Island. Ninety-two amphipods, mostly Ampelisca macrocephala, were permitted to feed until filled on meat of Alaskan brown bear (Ursus arctos) containing about 10 Trichinella larvae per gram. Immediately thereafter, the amphipods were killed by crushing and fed directly to two dogs, one receiving 57 and the other 35 . No larvae were found either by direct examination or by the digestion method when the dogs were killed 7 weeks later. Further experimentation of this type, using heavily infected meat and larger numbers of amphipods, has been planned.

\section{Summary and conclusions}

Although the basic diet of walrus throughout the Arctic consists of molluscs and other benthic invertebrates, mammalian flesh is sometimes eaten by an unknown proportion of the populations. These carnivores are of two types: facultative, which eat flesh when benthos is not available, and obligate, which subsist principally or exclusively on flesh. The kinds of mammals eaten generally are ringed and bearded seals and may also include cetaceans. It is believed that some are captured and killed by the walrus, but proof of predation has not been obtained.

The apparent similarity between the diets of carnivorous walrus, especially of those that are obligate carnivores, and polar bears is the basis for considering the possibility of parallel pathologic conditions (hypervitaminosis-A and trichinosis). There is evidence of these conditions in walrus, but further investigations are needed to provide proof of correlation with diet.

Walrus are important as a potential source of trichinosis transmissible to man, but in general the small proportion of walrus infected and the Eskimos' methods of food preparation seem to exclude the possibility of serious or especially frequent infection. Positive reactions to intradermal tests with Trichinella antigen have been observed in about 26 per cent of 598 Eskimos from Alaskan and Canadian communities where walrus are eaten (Brown et al. 1949b, Brown et al. 1950, Rausch et al. 1956). Although the percentage of reactors varies widely (9 to 45 per cent) in different localities, the overall infection rate indicated by the tests does not appear to be significantly higher than the known rate (16 to 23 per cent at autopsy, Gould 1945, p. 61) in the people of the continental United States. With progressive acculturation (which seems inevitable) and consequent adoption of more effective cooking techniques, the Eskimos' chances of contracting trichinosis should decrease appreciably. 


\section{References}

Bailey, A. M., and R. W. Hendee. 1926. Notes on the mammals of northwestern Alaska. J. Mamm. 7:9-28.

Brooks, J. W. 1954. A contribution to the life history and ecology of the Pacific walrus. Alaska Coop. Wildl. Res. Unit, Special Rept. No. 1, 103 pp.

Brown, M., B. Cronk, F. deSinner, J. E. Green, J. E. Gibbons, and E. Kuitunen-Ekbaum. 1949a. A note on trichinosis in animals of the Canadian Northwest Territories. Can. J. Pub. Health 40:20-1.

Health 40:508-13.

Brown, M., J. E. Green, T. J. Boag, and E. Kuitunen-Ekbaum. 1950. Parasitic infections in the Eskimos at Igloolik, N. W. T. Can. J. Pub. Health 41:508-12.

Brown, R. 1868. Notes on the history and geographical relations of the Pinnipedia frequenting the Spitzbergen and Greenland Seas. Proc. Zool. Soc. London 1868:405-40.

Cameron, T. W. M. 1957. Parasitology and the Arctic. Trans. Roy. Soc. Canada 51 (ser. 3, sec. 5):1-10.

Chapskii, K. K. 1936. Walrus of the Kara Sea. Leningrad, Vsesoiuznyi arkticheskii inst. Trudy 67:1-124 (In Russian with English summary).

Collins, H. B. 1956. Vanished mystery men of Hudson Bay. National Geographic Magazine 110:669-87.

Connell, F. H. 1949. Trichinosis in the Arctic: a review. Arctic 2:98-107.

Fay, F. H. 1955. The Pacific walrus (Odobenus rosmarus divergens): spatial ecology, life history, and population. Ph.D. thesis. Univ. of Brit. Col. $171 \mathrm{pp.}$

Freuchen, P. 1935. Mammals. Part II. Field notes and biological observations. Rept. Fifth Thule Exped. 2(4-5):68-278.

Gould, S. E. 1945. Trichinosis. Springfield, I1l.: Thomas, 356 pp.

Hantzsch, B. 1913. Beobachtungen über die Säugetiere von Baffinsland. Sitzungsb. Gesellsch. naturforsch. Freunde, Berlin 1913:141-60.

Hediger, H. 1955. Studies of the psychology and behaviour of animals in zoos and circuses. Translation by G. Sircom. London: Butterworths, $166 \mathrm{pp}$.

Høygaard, A. 1937. Innen for drivisen. Oslo, p. 104 (Cited in Rodahl, 1949). (Im Treibeisgürtel. Braunschweig: Westermann, $127 \mathrm{pp}$. [1940]).

Johansen, F. 1912. Observations on seals (Pinnipedia) and whales (Cetacea) made on the Danmark-Expedition 1906-08. Medd. om Grønl. 45: 201-24.

Kleinenberg, S. E. 1957. On the protection of walrus. Priroda 1957(7):101-3 (In Russian).

Klutschak, H. 1881. Als Eskimo unter den Eskimos. Leipzig, p. 219 (Cited in Rodahl, 1949).

Kuitunen, E. 1954. Walrus meat as a source of trichinosis in Eskimos. Can. J. Pub. Health 45:30.

McLaren, I. A. 1958. The biology of the ringed seal (Phoca hispida Schreber) in the Eastern Canadian Arctic. Fish. Res. Bd. Canada Bull. No. 118, 97 pp.

Mansfield, A. W. 1958. The biology of the Atlantic walrus, Odobenus rosmarus rosmarus (Linnaeus) in the Eastern Canadian Arctic. Fish. Res. Bd. Canada Ms. Rept. (Biol.) No. $653,146 \mathrm{pp}$.

Nieman, C., and H. J. K. Obbink. 1954. The biochemistry and pathology of hypervitaminosis A. In Vitamins and hormones, advances in research and applications. Vol. XII. Edited by R. S. Harris, G. F. Marrian, and K. V. Thimann. New York: Academic Press, pp. 69-99.

Nikulin, P. G. 1941. Chukotsk walrus. Vladivostok, Tikh. nauchno-issled. inst. ryb. okeanog. Izvestiya 20: 21-59 (In Russian).

Okak, G. 1956. Wintered walrus. Anchorage, Alaska: Anchorage Daily News, April 23, 1956.

Parnell, I. W. 1934. Animal parasites of North-East Canada. Can. Field Nat. 48:111-5. 
Pedersen, A. 1931. Fortgesetzte Beiträge zur Kenntnis der Säugetier- und Vogelfauna der Ostküste Grönlands. Medd. om Grønl. 77:341-506.

1945. Der Eisbär (Thalarctos maritimus Phipps). Copenhagen: E. Bruun, $166 \mathrm{pp}$.

Pikharev, G. A. 1941. Some data on the food of Far Eastern bearded seals (Erignathus barbatus Pall.). Vladivostok, Tikh. nauchno-issled. inst. ryb. okeanog. Izvestiya 20:101-20 (In Russian).

Rausch, R. 1952. Studies on the helminth fauna of Alaska. XI. Helminth parasites of microtine rodents. Taxonomic considerations. J. Parasit. 38:415-44.

Rausch, R., B. B. Babero, R. V. Rausch, and E. L. Schiller. 1956. Studies on the helminth fauna of Alaska. XXVII. The occurrence of larvae of Trichinella spiralis in Alaskan mammals. J. Parasit. 42:259-71.

Rodahl, K. 1949. The toxic effect of polar bear liver. Norsk Polarinst. Skr. Nr. 92,90 pp. 1950. Hypervitaminosis A. Norsk Polarinst. Skr. Nr. 95, 206 pp.

Roth, H. 1950. Nouvelles expériences sur la trichinose avec considérations spéciales sur son existence dans les régions arctiques. Off Int. Epizooties, Rapp. 18th Sess., pp. 1-24.

Roth, H., and H. Madsen. 1953. Die Trichinose in Grönland, abschliessender Bericht der Jahre 1948-1953. Proc. 14th Int. Cong. Zool., Sec X Parasit., pp. 340-1.

Schumach, M. 1958. "Bertha the whale flies in safely but pool mate awes her utterly." The New York Times. September 5, 1958.

Skeller, E. 1948. Trichinose i Kudligssat. Ugeskr. for laeger 110:602-7.

Thorborg, N. B., S. Tulinius, and H. Roth. 1948. Trichinosis in Greenland. Acta Pathol. 25:778-94.

Thorshaug, K., and A. F. Rosted. 1956. Researches into the prevalence of trichinosis in animals in arctic and antarctic waters. Nord. Vet. Med. 8:115-29.

Tsalkin, V. I. 1937. Materials on the biology of the walrus of Franz Josef Archipelago. Mosk. obshch. prirody. Biull. (biol., n. s.) 46:43-51 (In Russian).

Vibe, C. 1950. The marine mammals and the marine fauna in the Thule district (Northwest Greenland). Medd. om Grønl. 150(6):1-115. 